\title{
Global Challenges: Climate Chaos and the Future of Development
}

\section{Wolfgang Sachs}

\author{
1 Introduction \\ When I was invited to speak at the IDS fortieth \\ anniversary conference, I was asked to be both \\ challenging and brief. So in the short space available \\ now for this article, I must be selective. In order to \\ do that, I need to make you aware of two of my \\ preconceptions.
}

The first is my belief that what once was called development research is, in fact, an attempt at both the theory and practice of cosmopolitanism. By cosmopolitanism, I mean the effort to make the world a more hospitable place for all its citizens. But I also believe that the language, the semiotics of development today is an obstacle to engaging in the theory and practice of cosmopolitanism.

My second preconception is to believe that there will be no cosmopolitanism in this century unless it is green - or, you can forget about fighting for global fairness if you choose not to be an environmentalist. I am fully conscious of how, over the last two or three decades, the environment has become an add-on to everything but in contrast to that, I would argue that environmentalism is key to successfully tackling a host of conventional development issues, such as economic growth, equity, human rights and wellbeing.

The next sections divide my reflections into five points. Section 2 discusses the special case of European development and Section 3, the bifurcation of development. Section 4 is about the post-development era; Section 5 about contraction and convergence and Section 6 reviews sustainable prosperity.

\section{Europe: the special case}

When I reflect on Europe, I always want to ask the age-old question: Why was Europe able to leap ahead of the rest of the world when it did?
Historians and theoreticians have come up with a range of answers: Europe has benefited from an entrepreneurial spirit, it benefited from its liberal institutions, from its diversity, from its temperate climate. But I want to focus instead on what you might call an 'environmental hypothesis', first suggested, I think, by Kenneth Pomeranz in his book about the great divergence between the West and the rest, and in particular, China. Pomeranz wondered how and why Britain succeeded in moving ahead of China, given the fact that in the late eighteenth century, China was roughly equal in its potential to Europe, and Britain was roughly equal to the area of the Yangzi Delta.

Pomeranz points out that both economies were facing similar constraints at that time - which was that both societies were pushing at the limits of their growth and were particularly constrained by scarcity of land. In Europe, this was translating into scarcity of wool, timber and other resources. Similar things were happening in China, where land was so scarce it was not possible to grow enough food and fodder or produce enough fibre or fuel.

So how did Britain succeed in overcoming these resource constraints? There are in fact two reasons, the first being that Britain was able to tap into the crust of the earth to exploit coal for industrial purposes (and at that time, one ton of coal was approximately equivalent to five acres of sustainable timber production). The second reason was that Britain was able to reach out to foreign countries and to import massive amounts of agricultural goods from the New World, from the Caribbean, from the north-east of Brazil, from the south of today's USA, giving Britain access to timber, sugar, tobacco and many other products. Put simply, in the 1830s and 1840s, Britain had access to more than double its 
own arable land outside its own borders. In a nutshell, Britain was successful because it has access to mineral resources from the crust of the earth and to biotic resources from the colonies.

Carbon and colonies made everything else possible in other words industrial society would not exist in today's shape, had not resources been mobilised from both the depths of geological time and the expanse of geographical space. These were the special conditions that brought about the rise of the Euro-Atlantic civilisation.

\section{A bifurcated choice for the future}

In hindsight, Europe's development path turns out to be a special case; it cannot be repeated everywhere and any time. For the wealth of fossil and renewable raw materials at Europe's disposal in the nineteenth and twentieth centuries is no longer available. Today that resource bonanza is over and we are facing not only the end of the era of cheap oil but also climate chaos - and 'climate chaos' is the only precise term for it, as 'global warming' and 'climate change' are only euphemisms. Furthermore, the colonies no longer exist, so large developing countries need to turn inward to create their own domestic colonies if they want to exploit land resources as Britain did 200 years ago

So there is a crisis coming our way - and one we are well aware of. China is the most visible example of where we stand in the scramble for carbon and colonies today. The rise of China is a success in terms of development, in terms of economic growth and in terms of reducing the number of people living in absolute poverty. But it is a bittersweet success, because we already see dwindling water reserves, shrinking crop fields, soil erosion and other environmental consequences. It is clear how much China is going to weigh on the rest of the world, as it goes around like a vacuum cleaner sucking up resources in Latin America and in Africa and in parts of Asia; be it copper from Chile, oil from West Africa or soya beans from Brazil. We are facing a crunch situation - that using this model exiting from underdevelopment and poverty implies entering an environmental robber economy. That is the dilemma and no-one has any clear notion of how we can move forward.

It should be apparent that the European model of wealth generation and accumulation, which happened in historically exceptional conditions, cannot be transferred to the rest of the world. In other words, the model is structurally incapable of justice, so it is unwise to look at industrial patterns of production and consumption as we know them, as a standard for equity. It is difficult to see how the automobile society can be democratised across the world; it is difficult to see how chemically dependent agriculture can be replicated; it is difficult to see how a meat-based food system can be generalised. The resources required for extending and democratising this kind of wealth are too vast, they are too expensive, and they are too damaging for local and for global ecosystems.

This thus presents us with the bifurcation I mentioned above, and which I see in the following way. Either wellbeing remains confined to a minority because the prevailing styles of production and consumption cannot be generalised across the globe or sustainable models of wellbeing take hold, opening the opportunity for sufficient prosperity for all. Since both affluence and equity cannot be attained, one can either opt for affluence along with oligarchy or for sufficiency along with equity. Seen from this perspective, the choice between destructive and sustainable models of wealth is not so much a choice which separates the exploiter of nature from the lover of nature as it is a choice which separates the elitist from the democrat. In any case, production and consumption patterns will not be capable of justice unless they are resource-light and compatible with living systems. In the twenty-first century, there will be no equity without ecology.

\section{The post-development era}

What are the implications of this for development research? First, development - for the last 50-60 years (at least) the conceptual cornerstone of the development discourse has been to link the pursuit of justice to the idea of development. For many well-intentioned people, development meant to get ahead, to aspire to the same level as the more powerful countries and peoples. The development ideal has come to mean expanded participation in economic growth - that famous metaphor of the rising tide lifting all our boats. That was the hope for development - that with increasing growth it would be possible to solve the issue of equity.

But the emergence of biophysical limits has brought us into a different arena. Growth has lost its 
innocence and as long as the desire for justice and for recognition is linked to growth, we can expect a collision with bio-spherical stability. For decades, conventional development has defined equity as being a problem of the poor. Development experts used to highlight the lack of income, the lack of market access, the lack of capacity. To address this, development has advocated remedies to raise living standards - all kinds of solutions to raise the floor, but rarely have development experts spoken about modifying or even bringing down the ceiling. We often speak about equity in terms of the poor, while it is clear that given the biophysical limits of growth we now face, it is the rich and their economy that has to be called into question. In a nutshell, poverty alleviation cannot be separated from wealth alleviation. Anyone who speaks of poverty alleviation without wealth alleviation is, I suggest, someone we should rightly be suspicious of.

\section{Contraction and convergence}

The notion of contraction and convergence comes from climate policy, but needs to be considered from a much broader perspective. Contraction and convergence is, I suggest, a model that speaks about two paths of evolution. On the one hand it speaks about the global North, which puts considerable strains on its use of the global environmental space. And it is also clear from an equity point of view that no people or country can be permitted to take a disproportionate share of the environmental space because it is quite simply unjust to have institutional patterns of resource-use based on rules that cannot also be adopted by other countries.

In order to achieve global environmental justice, we must therefore promote a retreat by the North from its excessive use of environmental space. Contraction of resource consumption, therefore, is the trajectory of contraction upon which the North will have to embark. What it would mean for a country like Germany, for example, to become sustainable in ecological terms or in terms of equity, is that we would need to think about a reduction of 80-90 per cent in the consumption of fossil resources. And if we are serious about development, we must make that the mainstay of our policy - to persuade the North to weigh much more lightly on the planet.

A second area which development research must address is convergence. You might think those who have not enjoyed the same use of environmental space are entitled to have more; are entitled to increase their resource-use; are entitled to move a little way above the dignity line. Yes, developing countries need to have the space to realise their ideas of a flourishing society, although it cannot be imagined that this increase can mimic the trajectory taken in the past by Northern countries. It can be a rise but it will have to flatten out much sooner (relatively) until all countries are in a common corridor with sustainable rates of resource-use.

This, in summary, is the model of contraction and convergence. It follows directly from thinking about post-development, reconceptualising justice in an age after development.

\section{Sustainable prosperity}

When we look back at what was made possible by the availability of carbon and colonies, we see that they made it possible to build a material world which is largely independent of particular places, of particular seasons, of particular bodies. Architecture and agriculture provide the best examples. Modern buildings are typically built of glass and concrete, materials that are not connected to any specific place. Modern settlements are usually laid out along a grid of highways, disregarding both landscape and historical ways of living. Furthermore, modern crop cultivation, following a single-crop mentality, replaces local biodiversity with artificial nutrients and pesticides in favour of a more ecosystem-

independent production. However, we are paying a heavy price for this placeless, timeless, lifeless functionality. The lack of local fit - the lack of adaptation has to be paid for with huge amounts of energy and imported materials. Buildings that disregard the sun require artificial heating or cooling. Plants that are cultivated outside of season require glasshouses, transport, energy. And so it goes on.

When regarding sustainable prosperity, apart from looking for new alternative technologies like wind energy; flushless toilets; low-speed travel or an indigenous food production system, I am implying that a resource-light, a solar economy will not come into being without a new appreciation for places, contexts and times. To make human systems fit with natural conditions is most aptly done by connecting them to local materials and energy flows. Sustainable prosperity calls for both technical and sociocultural alternatives - it calls for creating innovations and experiments in many places, linked by a common 
awareness for the finiteness of the earth, but diverse in their technical and cultural styles.

In conclusion, the quest for justice in the world, which is often hidden behind development speak, calls for a transition to sustainable, resource-light forms of prosperity. For the more affluent classes in North and South, that implies a reversal in thinking about justice: it is not so important to learn how to give more, but to learn how to take less. 